\title{
THE NATURE OF EROSIVE RAINFALL ON A TROPICAL VOLCANIC ISLAND WITH AN ELEVATED INTERIOR
}

\author{
Werner Ne/ ${ }^{1}$ and Themba Mongwa \\ Department of Geography and Environmental Science \\ University of Fort Hare \\ Alice, South Africa \\ Paul D. Sumner and Ryan L. Anderson
Department of Geography, Geoinformatics and Meteorology
University of Pretoria
Pretoria, South Africa

\author{
Kumar R. Dhurmea and Yadowsun Boodhoo \\ Mauritius Meteorological Services \\ Vacoas, Mauritius
Ravi Boojhawon and Soonil D.D.V. Rughooputh
Faculty of Science
University of Mauritius
Reduit, Mauritius

\begin{abstract}
Mauritius is a typical tropical volcanic island with a distinct elevated central plateau above 550 m.a.s.l. Rainfall depth, duration, intensity, kinetic energy, and erosivity were analysed for 385 erosive rainfall events at five locations over a five-year period (2004 to 2008). Two Mauritius Meteorological Services stations located on the west coast and three sited on the Central Plateau provide detailed rainfall data at 6-minute intervals. Erosive storm events are found to differ markedly between the coastal lowlands and the elevated interior with regard to the frequency, the total rainfall generated, the duration, total kinetic energy, and total erosivity of individual events. However, mean kinetic energy, mean and maximum rainfall erosivity $\left(\mathrm{El}_{30}\right)$, and maximum intensities $\left(\mathrm{I}_{30}\right)$ from individual erosive events do not show this distinct differentiation. The distribution of kinetic energy and erosivity generated by individual events at the two altitudes are also significantly different. Although erosivity measured during summer exceeds that recorded in winter, the data indicate that large percentages of winter rainfall events on Mauritius are erosive and rainfall from non-tropical cyclones can pose a substantial erosion risk. Soil erosion risk occurs from storm-scale to synoptic-scale events, and extreme rainfall events generate the bulk of the erosivity. This paper also highlights that the use of rainfall records at an event scale in soil erosion risk assessments on tropical islands with a complex topography increases the effectiveness of erosivity estimates. [Key words: erosivity, rainfall intensity, kinetic energy, Mauritius.]
\end{abstract}

\section{INTRODUCTION}

On tropical islands, erosive rainfall is related to rainfall depth, topography, and altitude (Joshua, 1977; Nigel and Rughooputh, 2010a) and can detach and transport 
large amounts of sediment (Calhoun and Fletcher, 1999). Erosion risk and soil loss are not necessarily only dependent on rainfall depth (or amount), but also on the physical characteristics of rainfall. On a global scale, divergent reports exist with regard to the effect of individual rainfall events on soil erosion. Very intense storms could produce the bulk of soil loss (Hudson, 1971; Rydgren, 1996), while the cumulative influence of more frequent but lower-magnitude events could overshadow the relatively smaller effect of high-intensity events (Boardman and Favis-Mortlock 1999; Trustrum et al., 1999).

Key processes in water erosion, especially the amount of soil detached, are related to rainfall intensity (Van Dijk et al., 2002). Soil splash rate is influenced by a combination of rainfall intensity and raindrop fall velocity (Ellison, 1944), while the extent of erosion caused by a rainfall event depends on the physical characteristics of the rainfall, which include intensity, amount, drop-size distribution, terminal fall velocity, wind speed, and inclination (Obi and Salako, 1995). Rainfall kinetic energy, in particular, has been suggested to influence sediment transport (Hudson, 1965) as well as act as an indicator of erosivity (Free, 1960; Ghadiri and Payne, 1977), and is used in soil erosion modeling (Morgan et al., 1998). Rainfall intensity can be measured directly, but measurements of kinetic energy and raindrop sizes are, in most cases, unavailable, hence the empirical relationships between rain intensity and kinetic energy (Nyssen et al., 2005).

Volcanic islands tend to have a raised interior due to the nature of their formation. Analysis of rainfall records show that the elevated interiors of most tropical volcanic islands have a significant influence on rainfall totals (Bender et al., 1985; Larsen and Simon, 1993; Barcelo et al., 1997; Yen and Chen, 2000). Soil erosion has long been recognized as an important land denudation process on tropical islands (Cooley and Williams, 1985; Lo et al., 1985), and Mauritius, like most tropical islands, has a high soil erosion risk because of its climate, rugged topography, and extensive sugarcane cultivation (Nigel and Rughooputh, 2010a). The elevated interior causes a large contrast in rainfall distribution due to upward forcing of the SE trade winds (Fowdur et al., 2006). Long-duration, high-intensity rainstorms occur frequently (Yahya et al., 2010), and the small size of the island, the relatively small basins, and the high discharge rates of its rivers make sediment delivery ratios at the outlets especially high during these events (WRU and GIBB, 2002).

Although data on rainfall intensity are commonly used to parameterize rainfall erosivity (Morgan, 2005) and measurement of rainfall intensity is recommended to facilitate erosivity calculations (Le Roux et al., 2005), most rainfall erosivity indexing in erosion modeling on tropical islands is through annual and monthly rainfall depth (e.g., Aguilar and Waite, 1991; Le Roux et al., 2005; Nigel and Rughupooth, 2010a; 2010b; Kamminga, 2008). Given the paucity of high-resolution rainfall data on tropical islands, this paper uses 6-minute-interval rainfall data to investigate the intensity, kinetic energy, and erosive attributes of individual rainfall events on the island of Mauritius. The island has an elevated interior, and the paper also aims to investigate the effect of elevation on erosive rainfall characteristics through contrasting two distinct altitudes: the west coast and the Central Plateau. The study also examines the possible implications for erosion risk on tropical volcanic islands. 


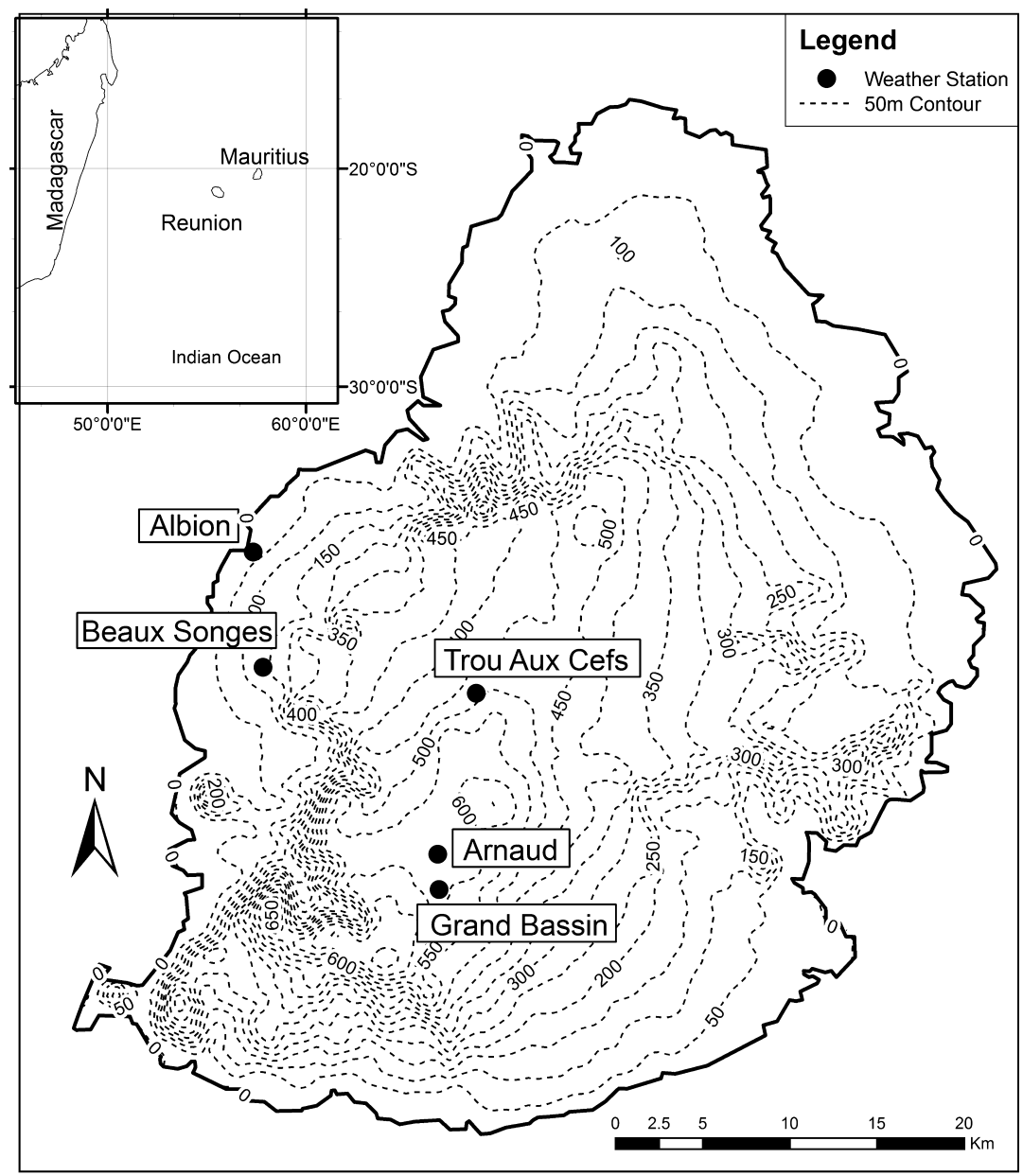

Fig. 1. Map of Mauritius showing the location of rainfall stations.

\section{STUDY SITES AND METHODOLOGY}

The island of Mauritius is located in the Indian Ocean at $20^{\circ} 10^{\prime} \mathrm{S}$ and $57^{\circ} 30^{\prime} \mathrm{E}$ and, together with Reunion and Rodrigues, forms the Mascarene Islands. All of the Mascarene Islands are the summits of volcanic cones that rose from the ocean floor. The north-south length of Mauritius is $63 \mathrm{~km}$ and the east-west width is $43 \mathrm{~km}$. Even though it has a complex topography, consisting of mountains, river valleys, and plains, a distinctive feature is the central plateau area that rises steadily towards the southwest of the island, bordered by remnants of the primary shield volcano as chain mountains (Johnson et al., 2010) (Fig. 1). The climate is tropical maritime with two seasons, a rainy summer from November to April, dominated by cyclone passage, and a dry winter from May to October, dominated by the SE trade winds and frontal systems (Nigel and Rughooputh, 2010b). Long-term (1971-2000) mean annual rainfall is 
$1400 \mathrm{~mm}$ on the eastern coast, $4000 \mathrm{~mm}$ in the central elevated interior, and $600 \mathrm{~mm}$ on the drier western coast (WRU, 2007). The Central Plateau at above 500 m.a.s.I. is only approximately $20 \mathrm{~km}$ from the west coast (Fig. 1), but long-term records indicate a large contrast in rainfall depth caused by the rain shadow effect of the elevated central uplands and its orographic forcing of the SE trade winds. Inter-annual variation in rainfall totals is significant as it depends on the passage of cyclones, which can double or triple the "normal" monthly rainfall amount received (Padya, 1989). The average rainfall from a tropical cyclone is $245 \mathrm{~mm}$ (Le Roux, 2005).

Rainfall data between 2004 and 2008 (five years) from automated weather stations at five locations on Mauritius were analyzed. The data were provided by the Mauritius Meteorological Services (MMS) and the Precis Mecanique R01-3030 rainfall gauges logged total rainfall every 6 minutes on a tipping resolution of 0.2 $\mathrm{mm}$ rainfall. Two sites are on the west coast of the island, one on the coast at Albion (12 $\mathrm{m}$ a.s.l.) and one approximately $4 \mathrm{~km}$ from the coastline at Beaux Songes (225 $\mathrm{m}$ a.s.l.). Data were also obtained from rainfall gauges in the Central Plateau area at Arnaud (576 m), Grand Bassin (605 m), and Trou aux Cerfs (614 m) (Fig. 1). The two west coast rainfall stations examine the rainfall intensity and possible erosivity in the driest part of the island, while the high-altitude stations provide a first attempt to present detailed rainfall data from the upper reaches of the catchments in the highest rainfall area. The following data were missing from all the station records; June and July records from 2004, November and December from 2006, and January, February, and March 2007. However, as these records were missing from all the stations, direct inter-station comparisons could still be made.

\section{Determining an Erosive Event}

Wischmeier and Smith (1958) indicated that rainfall intensities larger than 25 $\mathrm{mm} / \mathrm{h}$ are required for significant amounts of soil erosion to occur. Stocking and Elwell (1976) classified a distinct erosive rainfall event as a storm in which total rainfall exceeds $12.5 \mathrm{~mm}$, maximum 5 -minute intensity exceeds $25 \mathrm{~mm} / \mathrm{hour}$, and the event is isolated by at least a two-hour period of no rain. This definition was also applied to identify erosive events in the South African Drakensberg (Nel, 2007; Nel and Sumner, 2007). As the rainfall on Mauritius is logged every 6 minutes, the definition by Stocking and Elwell (1976) was adjusted for a 6-minute interval exceeding $12.5 \mathrm{~mm}$. Applying this definition, the data series from the five gauge locations used in this study indicate 385 individual erosive storm events during the study period.

\section{Determining Kinetic Energy}

Measurements of kinetic energy and raindrop size are unavailable, and an empirical relationship between rain intensity and kinetic energy is used. Wischmeier and Smith (1958) used measurements of drop-size characteristics and terminal velocity to derive a relationship between rainfall intensity and kinetic energy. The proposed relationship is a logarithmic function in the form:

$$
E_{\mathrm{k}}=11.87+8.73 \log _{10} R
$$


where the intensity $R$ is in $\mathrm{mm} / \mathrm{h}$. Work by Elwell and Stocking (1973) in Zimbabwe showed that for subtropical climates the kinetic energy of rainfall can be predicted by the equation:

$$
E_{\mathrm{k}}=(29.82-127.51 / R) \text { in } \mathrm{J} \mathrm{m}^{-2} \mathrm{~mm}^{-1}
$$

where the intensity $R$ is in $\mathrm{mm} / \mathrm{h}$. This equation has also been adopted for use in the SLEMSA (Soil Loss Estimation Model for Southern Africa). Van Dijk et al. (2002) critically appraised literature on the rainfall intensity-kinetic energy $\left(R-E_{\mathrm{k}}\right)$ relationship and, based on the average parameter values that were derived from the best datasets, gave the following general equation to predict storm kinetic energy content from rainfall intensity data:

$$
E_{\mathrm{k}}=28.3[1-0.52 \exp (-0.042 R)]
$$

where the intensity $R$ is in $\mathrm{mm} / \mathrm{h}$. As such, for the purpose of a comparative study on Mauritius, any of the three equations would suffice in estimating kinetic energy contents. To allow for consistency with global studies, the equation by Van Dijk et al. (2002) (Eq. 3) is used here to assess the 6-minute incremental kinetic energy content derived from rainfall intensity. In the analysis of kinetic energy, a uniform drop size distribution is assumed. Total event kinetic energy $\left(E_{\mathrm{k}}\right)$ generated during each individual erosive rainfall event $\left(\mathrm{J} \mathrm{m}^{-2}\right)$ is calculated through the 6-minute kinetic energy content, multiplied by the quantity of rain $(\mathrm{mm})$ falling in that specific 6 minutes to give the 6-minute kinetic energy. Each of the 6-minute kinetic energy values generated during the event is then summed to give the total kinetic energy during each individual event.

\section{Estimating Rainfall Erosivity Potential}

Soil erosion can be measured through process-based models such as the Water Erosion Prediction Project (WEPP) (Nearing et al., 1989) where inter-rill erosion or detachment $\left(D_{i}\right)$ is modeled as a function of the effective rainfall intensity $\left(I_{\mathrm{e}}\right)$. The European Soil Erosion Model (EUROSEM) (Morgan et al., 1998) predicts soil detachment by raindrop impact (DR) as a function of total kinetic energy (KE). Erosivity can be determined by the product $\left(\mathrm{El}_{30}\right)$ of the total kinetic energy $(\mathrm{E})$ of the storm times its maximum 30-minute intensity $\left(I_{30}\right)$, developed by Wischmeier and Smith (1978). This equation has been used globally as part of the (Revised) Universal Soil Loss Equation (R)USLE and also in Mauritius to assess the spatial distribution of erosivity (Le Roux, 2005) and reflects the combined potential of raindrop impact and turbulence created in overland flow. To be consistent with erosivity studies in Mauritius, the rainfall erosivity potential was determined by the product $\left(\mathrm{El}_{30}\right)$ of each individual storm $\left(\mathrm{mm} \mathrm{m} \mathrm{mm}^{-2} \mathrm{~h}^{-1}\right)$.

\section{CHARACTERISTICS OF EROSIVE RAINFALL EVENTS}

Of the 385 individual erosive rainfall events, the low-elevation west coast stations recorded 41 events at Albion and 47 at Beaux Songes. In the Central Plateau, 
Table 1. Erosive Rain Attributes as Measured at the Selected Stations on Mauritius (2004-2008)

\begin{tabular}{lccccccc}
\hline \hline & $\begin{array}{c}\text { Total } \\
\text { rainfall } \\
(\mathrm{mm})\end{array}$ & $\begin{array}{c}\text { Erosive } \\
\text { rainfall } \\
(\mathrm{mm})\end{array}$ & Pct. & $\begin{array}{c}\text { No. of } \\
\text { erosive } \\
\text { events }\end{array}$ & $\begin{array}{c}\text { Total } \\
\text { duration } \\
(\text { minutes })\end{array}$ & $\begin{array}{c}\text { Total kinetic } \\
\text { energy } \\
\left(\mathrm{J} \mathrm{m}^{-2}\right)\end{array}$ & $\begin{array}{c}\text { Total erosivity } \\
\left(\mathrm{mm} \mathrm{m}^{-2} \mathrm{~h}^{-1}\right)\end{array}$ \\
\hline $\begin{array}{l}\text { Albion } \\
(12 \text { m.a.s.l. })\end{array}$ & $3,516.6$ & $1,751.6$ & 50 & 41 & 18,353 & 30,626 & $1,011,410$ \\
$\begin{array}{l}\text { Beaux Songes } \\
(225 \text { m.a.s.l. })\end{array}$ & $3,825.0$ & $1,794.4$ & 47 & 47 & 17,886 & 32,257 & $1,035,703$ \\
$\begin{array}{l}\text { Arnaud } \\
(576 \text { m.a.s.l. })\end{array}$ & $15,207.8$ & $5,859.4$ & 39 & 115 & 80,622 & 100,082 & $3,094,191$ \\
$\begin{array}{l}\text { Grand Bassin } \\
(605 \text { m.a.s.I.) }\end{array}$ & $13,313.6$ & $4,963.6$ & 37 & 124 & 82,524 & 82,215 & $2,156,048$ \\
$\begin{array}{l}\text { Trou aux Cerfs } \\
(614 \text { m.a.s.I.) }\end{array}$ & $12,584.8$ & $3,322.6$ & 26 & 58 & 43,780 & 59,681 & $2,710,207$ \\
\hline
\end{tabular}

115 events were recorded at Arnaud, 124 at Grand Bassin, and 58 at Trou aux Cerfs (Table 1). Approximately half of all rainfall measured at the coast is of an erosive nature, while at the higher-altitude stations rainfall of an erosive nature is only between $26 \%$ and $39 \%$ of total rain recorded (Table 1). Total duration of events also vary markedly between the two coastal stations, and the higher-altitude stations with the duration of erosive rainfall events at Albion and Beaux Songes measuring less than 20,000 minutes, while at Trou aux Cerfs it is approximately double at 43,000 minutes and at Arnaud and Beaux Songes, erosive rainfall duration is more than four times that at the coast (Table 1).

With regard to total kinetic energy and erosivity measured, a marked increase in both total kinetic energy and total erosivity between the west coast stations and the high-altitude stations is apparent. Total kinetic energy measured at Arnaud and Grand Bassin is more than four times that measured at the low-altitude stations at Albion and Beaux Songes (Table 1). The erosivity of rainfall measured at the Central Plateau stations is also higher than that at low altitude, with Arnaud measuring three times more erosivity $\left(\mathrm{El}_{30}\right.$ ) than Albion and Beaux Songes (Table 1).

A breakdown of the annual distribution of rainfall characteristics is given in Table 2. Inter-annual variability can be discerned with regard to rainfall characteristics. However, if the annual totals from 2007 are disregarded (due to missing data), annual erosivity ranges between 2.2 million and 2.7 million $\mathrm{J} \mathrm{mm} \mathrm{m} \mathrm{m}^{-2} \mathrm{~h}^{-1}$.

A statistically significant $(p<0.001)$ positive correlation $(r=0.61, n=385)$ is found between individual erosive rainfall depth and duration (Table 3). Maximum 6-minute rainfall intensity $\left(\mathrm{I}_{6}\right)$ of erosive events measured at the different stations and maximum 30-minute $\left(\mathrm{I}_{30}\right)$ intensity are also positively correlated with rainfall depth, and strong, significant correlations between kinetic energy and erosivity of individual rainfall events and the event depth are shown. The duration of individual events also influences kinetic energy generated as well as erosivity, but the correlations are weaker than with rainfall depth (Table 3). However, a negative correlation 
Table 2. Annual Distribution of Erosive Rain Attributes Measured at the Selected Stations on Mauritius (2004-2008)

\begin{tabular}{lccccc}
\hline \hline Year & $\begin{array}{c}\text { Erosive } \\
\text { rainfall }(\mathrm{mm})\end{array}$ & $\begin{array}{c}\text { No of erosive } \\
\text { events }\end{array}$ & $\begin{array}{c}\text { Total duration } \\
(\text { minutes })\end{array}$ & $\begin{array}{c}\text { Total kinetic } \\
\text { energy } \\
\left(\mathrm{J} \mathrm{m}^{-2}\right)\end{array}$ & $\begin{array}{c}\text { Total erosivity } \\
\left(\mathrm{J} \mathrm{m} \mathrm{m} \mathrm{m}^{-2} \mathrm{~h}^{-1}\right)\end{array}$ \\
\hline 2004 & 5243.0 & 128 & 75,852 & 90,707 & $2,731,437$ \\
2005 & 5219.4 & 86 & 56,040 & 89,958 & $2,745,276$ \\
2006 & 3768.0 & 67 & 50,182 & 66,108 & $2,618,040$ \\
2007 & 995.8 & 24 & 14,380 & 16,970 & 434,312 \\
2008 & 4277.4 & 80 & 63,541 & 72,704 & $2,267,629$ \\
\hline
\end{tabular}

Table 3. Correlation Coefficient $(r)$ with Level of Significance $(p)$ of Attributes of Erosive Storms $(n=385)$ as Measured at Five Stations in Central and Western Mauritius

\begin{tabular}{|c|c|c|c|c|c|c|c|}
\hline & & Depth & Duration & $\mathrm{I}_{6}$ & $\mathrm{I}_{30}$ & $\begin{array}{l}\text { Kinetic } \\
\text { energy }\end{array}$ & Erosivity \\
\hline \multirow[t]{2}{*}{ Depth } & Spearman's correlation & \multirow{2}{*}{1} & $0.61^{* *}$ & $0.31^{* *}$ & $0.43^{* *}$ & $0.97^{* *}$ & $0.85^{* *}$ \\
\hline & Significance & & 0.00 & 0.00 & 0.00 & 0.00 & 0.00 \\
\hline \multirow[t]{2}{*}{ Duration } & Spearman's Correlation & $0.61^{* *}$ & \multirow{2}{*}{1} & $-0.26^{* *}$ & $-0.25^{* *}$ & $0.50^{* *}$ & $0.22^{* *}$ \\
\hline & Significance & 0.00 & & 0.00 & 0.00 & 0.00 & 0.00 \\
\hline
\end{tabular}

${ }^{* *}$ Correlation is significant at the $99 \%$ confidence level (2-tailed).

is found between duration of event and the maximum rainfall intensity $\left(\mathrm{I}_{6}\right.$ and $\left.\mathrm{I}_{30}\right)$. Even though these correlations are weak, they are significant at the $99 \%$ confidence level, indicating that the longer the duration of the events, the lower the maximum intensities.

Given the seasonality of rainfall on Mauritius (Padya, 1989) monthly rainfall for the recorded period at each station was compared to monthly erosive rainfall (Table 4). As anticipated, the summer months (November to March) produced the highest percentage of erosive rainfall, and late summer rainfall is particularly erosive, with January, February, and March producing $64 \%$ of the annual kinetic energy and $55 \%$ of annual erosivity, respectively (Table 4). However, the winter months did record erosive rainfall, with nearly half of all rainfall recorded in April and May being of an erosive nature. The rainfall in May was particularly erosive, with $13 \%$ of annual kinetic energy generated and $31 \%$ of total erosivity produced.

The attributes of individual erosive events measured at the individual stations are presented in Table 4. Maximum depth of rainfall measured during any individual event was $435.8 \mathrm{~mm}$ recorded at Arnaud and a separate event with the longest duration was also measured at this station (Table 5). Mean rainfall depth and mean 
Table 4. Monthly Characteristics of Erosive Events $(n=385)$

\begin{tabular}{lccccc}
\hline \hline Month & $\begin{array}{c}\text { Total rainfall } \\
(\mathrm{mm})\end{array}$ & $\begin{array}{c}\text { Erosive } \\
\text { rainfall }(\mathrm{mm})\end{array}$ & Pct. & $\begin{array}{c}\text { Total kinetic energy } \\
\text { (pct. of annual) }\end{array}$ & $\begin{array}{c}\text { Total erosivity } \\
\text { (pct. of annual) }\end{array}$ \\
\hline January & 5831.0 & 3838.0 & 66 & 21 & 19 \\
February & 5794.2 & 2580.6 & 45 & 14 & 11 \\
March & 9060.0 & 6256.6 & 69 & 29 & 25 \\
April & 3868.8 & 1683.4 & 44 & 8 & 6 \\
May & 5380.4 & 2156.6 & 40 & 13 & 31 \\
June & 3002.6 & 324.2 & 11 & 1 & 1 \\
July & 3945.6 & 939.2 & 24 & 3 & 1 \\
August & 2315.8 & 73.6 & 3 & 1 & 2 \\
September & 4692.8 & 731.4 & 16 & 4 & 0 \\
October & 1851.0 & 134.4 & 7 & 1 & 1 \\
November & 2069.0 & 415.4 & 20 & 2 & 2 \\
December & 2478.8 & 714.4 & 29 & 3 & \\
\hline
\end{tabular}

intensities from individual events show no altitudinal differences, but distinct differences are shown between the coast and the elevated stations with regard to maximum rainfall depth. In contrast, mean duration of rainfall events exhibits marked differences between coastal and plateau stations, but the differences are not as distinct with respect to maximum event duration and maximum intensities (Table 5).

Maximum kinetic energy produced during any individual storm was $7293 \mathrm{~J} \mathrm{~m}^{-2}$ recorded at Arnaud. Altitudinal differentiation with respect to maximum kinetic energy is evident, but not for mean kinetic energy (Table 5). Except for Trou aux Cerfs, where one extreme event produced erosivity $\left(\mathrm{El}_{30}\right)$ of over 800,000 J mm $\mathrm{m}^{-2} \mathrm{~h}^{-1}$, the other stations have quite similar mean rainfall erosivity and only slight increases of maximum rainfall erosivity with altitude.

The distribution of rainfall characteristics of individual events measured at the Central Plateau stations contrasts with the distribution of characteristics measured at the coastal stations through the non-parametric Mann-Whitney $U$ test (Table 6). The distribution of rainfall depth, duration, and intensities measured at the coast, compared to those measured at the Central Plateau, show no significant differences. However, the statistics show significant differences between the distribution of kinetic energy and erosivity measured at the two distinct altitudes.

In addition to erosive events, the occurrence of high-intensity rainfall events was also considered (Table 7). A high-intensity event is defined as one with maximum $\mathrm{I}_{30}$ greater than $50 \mathrm{~mm} / \mathrm{h}$ (Schulze, 1978; Nel and Sumner, 2007). Arnaud recorded the highest number of high-intensity rainfall events (27), while Grand Bassin recorded 5 and Trou aux Cerfs 6. The low-altitude stations (Albion and Beaux Songes) have the fewest high-intensity events with 2 and 4 recorded, respectively over the five-yr period. Rainfall events that show above-average kinetic energy were also evaluated. The rainfall events were divided into the number of events per station that 
Table 5. Attributes of Erosive Rainfall Events as Measured at Five Stations in Central and Western Mauritius

\begin{tabular}{|c|c|c|c|c|c|c|c|}
\hline Station & Attribute & $\begin{array}{l}\text { Storm } \\
\text { depth } \\
(\mathrm{mm})\end{array}$ & $\begin{array}{l}\text { Storm } \\
\text { duration } \\
\text { (min) }\end{array}$ & $\begin{array}{c}\text { Intensity } \\
\left(\mathrm{I}_{6}\right) \\
(\mathrm{mm} / \mathrm{h})\end{array}$ & $\begin{array}{c}\text { Intensity } \\
\left(\mathrm{I}_{30}\right) \\
(\mathrm{mm} / \mathrm{h})\end{array}$ & $\begin{array}{r}\text { Kinetic } \\
\text { Energy } \\
\left(\mathrm{J} \mathrm{m}^{-2}\right)\end{array}$ & 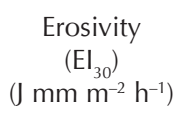 \\
\hline \multirow{2}{*}{$\begin{array}{l}\text { Albion } \\
\text { (12 m.a.s.l.) }\end{array}$} & Maximum & 177.6 & 2772 & 202 & 92 & 3015 & 131,136 \\
\hline & Mean & 44.4 & 463 & 59 & 29 & 798 & 26,241 \\
\hline \multirow{2}{*}{$\begin{array}{l}\text { Beaux Songes } \\
\text { ( } 225 \text { m.a.s.I.) }\end{array}$} & Maximum & 138.0 & 2256 & 116 & 59 & 2673 & 151,849 \\
\hline & Mean & 38.6 & 383 & 55 & 27 & 693 & 22,122 \\
\hline \multirow{2}{*}{$\begin{array}{l}\text { Arnaud } \\
\text { (576 m.a.s.I.) }\end{array}$} & Maximum & 435.8 & 4560 & 198 & 82 & 7293 & 235,963 \\
\hline & Mean & 51.8 & 734 & 52 & 24 & 891 & 27,199 \\
\hline \multirow{2}{*}{$\begin{array}{l}\text { Grand Bassin } \\
\text { (605 m.a.s.l.) }\end{array}$} & Maximum & 384.8 & 3846 & 122 & 82 & 6334 & 197,612 \\
\hline & Mean & 53.1 & 764 & 44 & 21 & 879 & 22,928 \\
\hline \multirow{2}{*}{$\begin{array}{l}\text { Trou aux Cerfs } \\
\text { (614 m.a.s.l.) }\end{array}$} & Maximum & 321.4 & 3666 & 198 & 138 & 5896 & 816,062 \\
\hline & Mean & 57.3 & 755 & 59 & 30 & 1029 & 46,728 \\
\hline
\end{tabular}

Table 6. $P$-values ${ }^{\text {a }}$ Derived from the Mann-Whitney $U$ Test between Distributions of Attributes of Individual Events Measured at the Central Plateau Stations versus Those Measured at Coastal Stations

\begin{tabular}{lccccc}
\hline \hline Storm depth & $\begin{array}{c}\text { Storm } \\
\text { duration }\end{array}$ & Intensity $\left(\mathrm{I}_{6}\right)$ & Intensity $\left(\mathrm{I}_{30}\right)$ & $\begin{array}{c}\text { Kinetic } \\
\text { energy }\end{array}$ & $\begin{array}{c}\text { Erosivity } \\
\left(\mathrm{EI}_{30}\right)\end{array}$ \\
\hline 0.06 & 0.00 & 0.01 & 0.04 & 0.37 & 0.30 \\
\hline
\end{tabular}

aSignificant difference if $p$-value is less than 0.05 (two-tailed).

have kinetic energy above certain thresholds (Table 7). Again, extreme events with a high energy content have marked altitudinal differentiation, with the coastal stations (Albion and Beaux Songes) recording fewer events with kinetic energy more than $1000 \mathrm{~J} \mathrm{~m}^{-2}$ and $2000 \mathrm{~J} \mathrm{~m}^{-2}$. Furthermore, no rainfall event produced more than 4000 $\mathrm{J} \mathrm{m}^{-2}$ of energy at the coast, whereas the three Central Plateau area stations measured a total of 8 such events.

To analyze the nature of erosive events measured at the stations, the cumulative kinetic energy produced by individual events was plotted against cumulative erosive events (Fig. 2). The graph is divided into quartiles, and the coastal stations of Albion and Beaux Songes (broken lines) show similar exponential distributions. This is also the case with the Central Plateau stations (solid lines). The data indicate that, for all stations, a quarter of rainfall events produce more than half of the total kinetic energy. One single event measured during May 2006 at Trou aux Cerfs generated $816,062 \mathrm{~J} \mathrm{~mm} \mathrm{~m}^{-2} \mathrm{~h}^{-1}$ (Table 5), which contributed $30 \%$ of the total erosivity measured at that particular station (Table 1). 
Table 7. Frequency of Extreme Events at the Individual Stations with Respect to Certain Thresholds

\begin{tabular}{lccccc}
\hline \hline Station & $\begin{array}{c}\text { N of events } \\
\left(\mathrm{I}_{30}>50 \mathrm{~mm} / \mathrm{h}\right)\end{array}$ & $\begin{array}{c}\text { Nof events } \\
(\mathrm{KE}>1000 \mathrm{~J} \\
\left.\mathrm{m}^{-2}\right)\end{array}$ & $\begin{array}{c}\mathrm{N} \text { of events } \\
(\mathrm{KE}>2000 \mathrm{~J} \\
\left.\mathrm{m}^{-2}\right)\end{array}$ & $\begin{array}{c}\mathrm{N} \text { of events } \\
(\mathrm{KE}>3000 \mathrm{~J} \\
\left.\mathrm{m}^{-2}\right)\end{array}$ & $\begin{array}{c}\text { N of events } \\
(\mathrm{KE}>4000 \mathrm{~J} \\
\left.\mathrm{m}^{-2}\right)\end{array}$ \\
\hline $\begin{array}{l}\text { Albion } \\
(12 \text { m.a.s.l. })\end{array}$ & 2 & 12 & 2 & 1 & 0 \\
$\begin{array}{l}\text { Beaux Songes } \\
(225 \text { m.a.s.l. })\end{array}$ & 4 & 8 & 2 & 0 & 0 \\
$\begin{array}{l}\text { Arnaud } \\
(576 \text { m.a.s.l. })\end{array}$ & 9 & 29 & 8 & 5 & 5 \\
$\begin{array}{l}\text { Grand Bassin } \\
(605 \text { m.a.s.l. })\end{array}$ & 5 & 30 & 14 & 7 & 1 \\
$\begin{array}{l}\text { Trou aux Cerfs } \\
(614 \text { m.a.s.I. })\end{array}$ & 6 & 16 & 7 & 4 & 2 \\
\hline
\end{tabular}

\section{DISCUSSION}

Places characterized by complex topography normally get rainstorms caused by topographic forms drawing out atmospheric moisture through orographic precipitation mechanisms (Barstad and Smith, 2004). The elevated interior of Mauritius represents such an environment and has a noticeable spatial difference in rainfall from east to west across the plateau of the island. Mean annual rainfall differs from 600 to $900 \mathrm{~mm}$ on the west coast to over $4000 \mathrm{~mm}$ on the central plateau (Rughooputh, 1997; WRU, 2007, Dhurmea et al., 2009), and this rainfall gradient is due to orographic effects on the SE trade winds caused by the south-eastern mountain range and the Central Plateau (Fowdur et al., 2006). This spatial differentiation is also evident in the nature of erosive rainfall recorded at the stations, with an increase in the frequency, total rainfall generated, duration, total kinetic energy, and total erosivity of erosive events between the coast and interior. Total kinetic energy measured on the Central Plateau is four times that measured at the coast, and erosivity $\left(\mathrm{El}_{30}\right)$ three times. This compares well with the only other actual $\mathrm{El}_{30}$ measured on Mauritius during 1995-1996 at Belle Rive in the Central Plateau and in Belle Ombre on the south coast (Le Roux, 2005).

Mauritius experiences two seasons, a rainy summer season from November to April and a dry winter from May to October (Padya, 1989). Monthly soil risk maps, developed by Nigel and Rughooputh (2010b), show that on an island scale, January and February have the highest erosion risk, followed by December and March, with the rest of the year being dominated by low and very low erosion risk. Data from individual erosive events broadly reinforce this spatial and temporal trend. However, a general description of an increase in erosivity with altitude and the seasonality in erosivity is inadequate in describing the erosive characteristics of individual rainfall events. Mean kinetic energy and erosivity produced from individual erosive events do not show a strong trend with altitude. Except for Trou aux Cerfs, maximum intensities $\left(\mathrm{I}_{30}\right)$ and maximum rainfall erosivity $\left(\mathrm{El}_{30}\right)$ have very limited spatial 


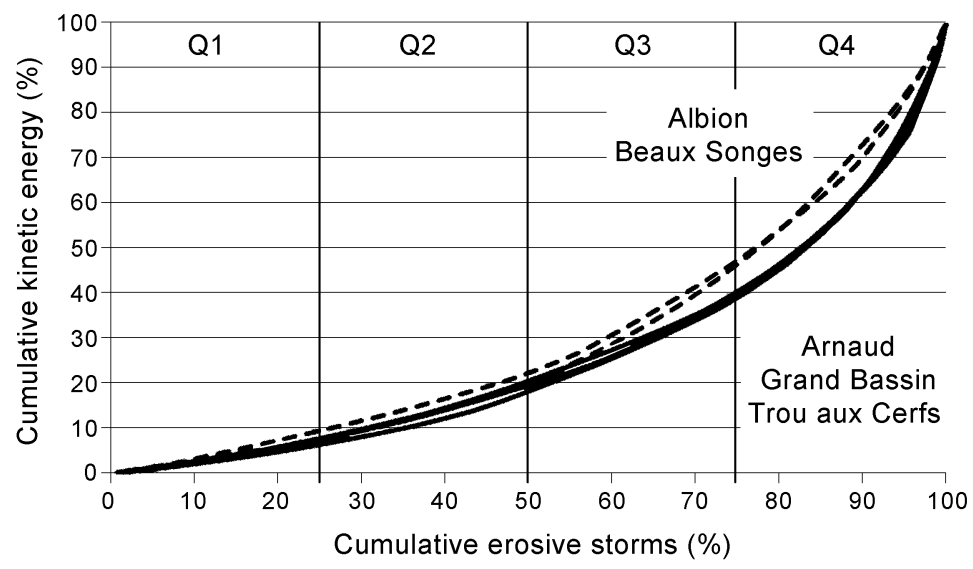

Fig. 2. Cumulative kinetic energy as a percentage of the erosive storms measured at the individual stations. The west coast stations are depicted by the broken lines, whereas the solid lines depict the Central Plateau stations.

difference. Furthermore, the data indicate that more than a third of winter rainfall on Mauritius at all altitudes is defined as erosive.

According to Padya (1989), the highest historical values of rainfall intensity recorded were in 1961, when a local shower in the southeast recorded a maximum $\mathrm{I}_{30}$ of $90 \mathrm{~mm} \mathrm{~h}^{-1}$, and in 1971 in the north when an $\mathrm{I}_{30}$ of $92 \mathrm{~mm} \mathrm{~h}^{-1}$ was recorded. These events were recorded manually through the use of recording sheets and it is reported that during very heavy rainfall, the sheets get wet and the smudged records cannot be interpreted (Padya, 1989). Even though the data from automated weather stations presented here are only for five years, they show that much higher rainfall intensities on Mauritius occur than those previously reported. Maximum intensities of over $130 \mathrm{~mm} \mathrm{~h}^{-1}$ were recorded at Trou aux Cerfs and, at the coast (Albion), a maximum $\mathrm{I}_{30}$ was recorded of $92 \mathrm{~mm} \mathrm{~h}^{-1}$ from a rainfall event lasting 60 minutes during March 2004. Therefore, use of historical sheet records as a means of confirming maximum intensities of rainfall events on Mauritius should be done with caution.

Extreme rainfall events also show a significant differentiation with altitude but, from the data, it is clear that, on the island, extreme events generate the bulk of the cumulative kinetic energy and erosivity at all altitudes. Spatial differences in total kinetic energy and erosivity are related to the total number of erosive rainfall events. High-altitude areas also receive more extreme rainfall events that then generate above-average kinetic energies and erosivity. The differences in erosivity between the coast and the elevated interior are thus not only related to absolute rainfall depth, but also to the nature of extreme rainfall events.

\section{IMPLICATIONS FOR SOIL EROSION RISK}

Erosion assessments on Mauritius have mainly used daily, monthly, or annual rainfall totals as an indication of rainfall erosivity. Kremer (2000) mapped the annual 
erosivity of Mauritius by classifying the number of days that receive $>50 \mathrm{~mm}$ of rain over a year using daily rainfall depth data over a five-year period. Le Roux et al. (2005) estimated soil loss for a river basin on the island using the RUSLE model and GIS. In the absence of 6-minute data, the rainfall erosivity (R value) was obtained through monthly and annual rainfall as input into a Modified Fournier Index (MFI) developed by the FAO (Arnoldus, 1980). A recent soil erosion risk assessment (Nigel and Rughooputh, 2010a, 2010b) also uses monthly rainfall and annual data as input into the MFI to classify monthly erosivity on an island scale. However, erosion risk and soil loss are not only dependent on rainfall depth, but also on the physical characteristics of rainfall. In certain areas (especially the tropics) very intensive storms are responsible for the bulk of the predicted soil loss (Suarez de Castro, 1950; Hudson, 1971). In contrast, it has also been reported that large storms appear to play a lesser role compared with the cumulative influence of more frequent, lower-magnitude events (Boardman and Favis-Mortlock 1999; Trustrum et al., 1999). Even though soil loss from individual events can vary greatly and is dependent on vegetation cover and recent tillage (Le Roux 2005), here we show that the less-frequent, large-rainfall events produce the bulk of rainfall erosivity.

It has been shown that significant erosion risk on Mauritius is posed by summer rainfall through tropical cyclones (Padya, 1989; Le Roux, 2005; Nigel and Rughooputh, 2010b). The data presented here reinforce this assessment, but extreme non-tropical cyclone rainfall can also represent an erosion risk. Even though the detailed meteorological assessment of individual rainfall events is not considered here, some preliminary appraisals are made. Significant erosive rainfall fell during May 2008 at all altitudes during the recording period, when two cold fronts crossed the island on May 16 and 19, followed by easterly waves. A very unstable atmosphere also contributed to the rainfall recorded (Mauritius Meteorological Services, 2008). This frontal mesoscale rainfall caused a significant amount of the total erosivity recorded during the five-year period. One rainfall event on March 8, 2004, measured at Albion, contributed $13 \%$ of the total erosivity measured at that station for the five-year period as well as the highest intensity $\left(I_{30}\right.$ of $\left.92 \mathrm{~mm} \mathrm{~h}^{-1}\right)$. The event lasted an hour and, as very little rainfall was recorded at the other stations, it is assumed that it was not related to a cyclone and instead was probably due to localized convective rainfall associated with thunderstorm (storm-scale) activity.

The differentiation of rainfall energy and erosivity between the coast and the upper catchment areas is undisputed and must have a bearing on the detachment of soil particles and runoff rates. Furthermore, any poorly vegetated area in the highaltitude mountains will be at risk of erosion (Le Roux, 2005) and the high-altitude areas have been classified as areas of high erosivity (Nigel and Rughooputh, 2010a). More than half of the area of Mauritius is under intensive cultivation, mostly sugar cane, but the sugarcane industry in Mauritius has been facing enormous economic constraints (Le Roux, 2005). To counter this, a number of fields, especially on the west coast, are being converted to other agricultural crops (Kamminga, 2008), although sugarcane crop conversion can pose a massive soil erosion risk (Le Roux, 2005). Traditionally, the risk of erosion on the west coast for most of the year and for most types of agricultural land use has been viewed as limited (Kamminga, 2008; Nigel and Rughooputh, 2010a; 2010b), and vulnerability analysis indicates that, on the 
west coast, crop conversions are not linked to soil erosion risk (Kamminga, 2008). This could be attributed to the fact that current soil erosion models on Mauritius estimate rainfall erosivity from monthly and annual rainfall totals, but this paper shows that erosion risk from individual events on Mauritius can occur at all altitudes (including the west coast) from all rain-bearing weather conditions. In such an environment, where a small number of individual events generate high erosivity, annual or monthly rainfall measurements could be underestimating erosion risk at the island scale. Therefore, the temporal scale of data used to detect soil erosion risk in an environment where storm- to synoptic-scale systems dominate the risk for soil erosion needs to be adjusted to smaller time-scales to increase effective assessment.

\section{CONCLUSION}

Mauritius, like most tropical volcanic islands, is an environment where there is a noticeable altitudinal and temporal difference in rainfall due to the nature of the topography and its orographic effects. Data from individual erosive events broadly reinforces these distinct trends. Erosive rainfall recorded at the stations show marked differences between the west coast and the higher-altitude Central Plateau in frequency, total rainfall generated, total kinetic energy, and the total erosivity of individual events. Erosivity measured during summer also exceeds that recorded in winter, and the distribution of kinetic energy and erosivity measured at the two distinct altitudes are also significantly different. However, a general description of spatial and temporal differentiation is inadequate in describing the characteristics of individual rainfall events. Mean kinetic energy, mean and maximum rainfall erosivity $\left(\mathrm{El}_{30}\right)$, and maximum intensities $\left(\mathrm{I}_{30}\right)$ from individual erosive events do not have this strong spatial trend. The data also indicate that large percentages of winter rainfall on Mauritius at all altitudes are defined as erosive, and non-tropical cyclone rainfall can pose a substantial erosion risk. Extreme rainfall events generate the bulk of the cumulative erosivity at all altitudes, and the spatial differences in erosivity are related to the total number of erosive rainfall events as well as the frequency of extreme rainfall events.

High-resolution intensity data from automated weather stations show that greater rainfall intensities occur than were previously recorded manually. The use of manual sheet records as a means to validate maximum intensities and erosivity on a spatial and temporal scale on Mauritius should be done with care. Furthermore, in rainfall erosivity modelling in a tropical maritime environment like Mauritius, the time scale at which rainfall records are used within these assessments needs to be at an event scale (storm and synoptic scale) to be effective. Given the findings, it is suggested that further research into the causes and nature of extreme rainfall events and the implication for soil erosion risk is needed.

Acknowledgments: WN and PS acknowledge funding from the National Research Foundation (NRF) through the incentive grants for rated researchers, but any opinions expressed are those of the authors, for which the NRF does not accept any liability. The Department of Geography, Geoinformatics, and Meteorology at the University of Pretoria and the Govan Mbeki Research and Development Centre at the University of Fort Hare supplied additional travel funding for WN, PS, RB, and TM. 


\section{REFERENCES}

Aguilar, R. and Waite, M. (1991) Soil depth characteristics and erosion estimates along the Hamakua Coast, Island of Hawaii. Journal of Hawaiian Pacific Agriculture, Vol. 3, 39-51.

Arnoldus, H. M. J. (1980) An approximation of the rainfall factor in the Universal Soil Loss Equation. In M. De Boodt and D. Gabriels, eds., Assessment of Erosion. Chichester, UK: John Wiley \& Sons Ltd., 127-132.

Barstad, I. and Smith, R. B. (2004) A linear theory of orographic precipitation. American Meteorological Society, Vol. 6, 1377-1391.

Barcelo, A., Robert, R., and Coudray, J. (1997) A major rainfall event: The 27 February-5 March 1993 rains on the southeastern slope of Piton de la Fournaise Massif (Reunion Island, southwest Indian Ocean). Monthly Weather Review, Vol. 125, 3341-3346.

Bender, M. A., Tuleya, R. E., and Kurihara, Y. (1985) A numerical study of the effect of a mountain range on a landfalling tropical cyclone. Monthly Weather Review, Vol. 113, 567-582.

Boardman, J. and Favis-Mortlock, D. (1999) Frequency-magnitude distributions for soil erosion, runoff, and rainfall_-a comparative analysis. Zeitschrift für Geomorphologie, Vol. 115, 51-70.

Calhoun, R. S. and Fletcher, C. H., III (1996) Late Holocene coastal plain stratigraphy and sea-level history at Hanalei, Kauai, Hawaiian Islands. Quaternary Research, Vol. 45, 47-58.

Cooley, K. R. and Williams, J. R. (1985) Applicability of the universal soil loss equation USLE and the modified USLE to Hawaii. In S. A. El-Swaify, W. C. Moldenhauer, and A. Lo, eds., International Conference on Soil Erosion and Conservation, "Malama Aina 83." Honolulu, HI: Soil Conservation Society of America and University of Hawaii, Department of Agronomy and Soil Science, 509-522.

Dhurmea, K. R., Boojhawon, R., and Rughooputh, S. D. D. V. (2009) Geostatistical approaches for estimating rainfall over Mauritius. Research Week, University of Mauritius, Reduit, Mauritius. Retrieved from http://vcampus.uom.ac.mu/researchweek/conference2009/uploads/paper1049595.pdf

Ellison, W. D. (1944) Studies of raindrop erosion. Agricultural Engineering, Vol. 25, $131-136$.

Elwell, H. A. and Stocking, M. A. (1973) Rainfall parameters for soil loss estimation in a subtropical climate. Journal of Agricultural Engineering Research, Vol. 18, 169-177.

Fowdur, S. C., Virasami, S., Cheeneenbash, J., Boojhawon, R., and Rughooputh, S. D. D. V. (2006) Evidence for topography-enhanced precipitation over Mauritius. In Proceedings 21: Colloquium on African Geology. Maputo, Mozambique.

Free, F. (1960) Erosion characteristics of rainfall. Agricultural Engineering, Vol. 41, 447-449.

Ghadiri, H. and Payne D. (1977) Raindrop impact stress and the breakdown of soil crumbs. Journal of Soil Science, Vol. 28, 247-258. 
Hudson, N. W. (1965) The Influence of Rainfall on the Mechanics of Soil Erosion with Particular Reference to Southern Rhodesia. Unpublished master's thesis, University of Cape Town, Cape Town, South Africa.

Hudson, N. W. (1971) Soil Conservation. Ithaca, NY: Cornell University Press.

Johnson, C. P., Seth, H. C., and Ollier, C. D. (2010) Geological attractions for tourists in Mauritius. In R. K. Dowling and D. Newsome, eds., Global Geotourism Perspectives. Oxford, UK: Goodfellow Publishers.

Joshua, W. D. (1977) Soil erosive power of rainfall in the different climatic zones of Sri Lanka. In Erosion and Solid Matter Transport in Inland Waters. Paris: IAHSAISH, Proceedings of Symposium Publication No.122, 51-61.

Kamminga, A. T. (2008) Vulnerability Assessment of Potential Soil Erosion: A Case Study on Mauritius. Unpublished master's thesis, University of Mauritius, Reduit, Mauritius.

Kremer, M. (2000) Aspekte der Bodenerosion in Mauritius-Analysis verschiedener Einflussfaktoren an ausgewahlten Standorten mit hilfe Geographischer Informationssysteme (GIS) [Aspects of Soil Erosion in Mauritius-Analysis of Various Factors in Selected Locations with the Help of Geographic Information Systems (GIS)]. Unpublished thesis (Diplomarbeit), Philips-University, Marburg, Germany.

Larsen, M. C. and Simon, A. (1993) A rainfall intensity-duration threshold for landslides in a humid-tropical environment, Puerto Rico. Geografiska Annaler Series A, Vol. 75, 13-23.

Le Roux, J.J. (2005) Soil Erosion Prediction under Changing Land Use on Mauritius. Unpublished master's thesis, University of Pretoria, Pretoria, South Africa.

Le Roux, J. J., Sumner, P. D., and Rughooputh, S. D. D. V. (2005) Erosion modelling and soil loss prediction under changing land use for a catchment on Mauritius. South African Geographical Journal, Vol. 87, 127-140.

Lo, A., El-Swaify, S. A., Dangler, E. W., and Shinshiro, L. (1985) Effectiveness of $\mathrm{El}_{30}$ as an erosivity index in Hawaii. In S. A. El-Swaify, W. C. Moldenhauer, and A. Lo, eds., International Conference on Soil Erosion and Conservation, "Malama Aina 83." Honolulu, HI: Soil Conservation Society of America and University of Hawaii, Department of Agronomy and Soil Science, 384-392.

Mauritius Meteorological Services (2008) Technical Report CS 28: Cyclone Season of the Southwest Indian Ocean 2006-2007. Vacoas, Mauritius: Mauritius Meteorological Services.

Morgan, R. P. C. (2005) Soil Erosion and Conservation (3rd ed). Oxford, UK: Blackwell Publishing.

Morgan, R. P. C., Quinton, J. N., Smith, R. E., Govers, G., Poesen, J. W. A., Auerswald, K., Chisci, G., Torri, D., and Styczen, M. E. (1998) The European soil erosion model (EUROSEM): A dynamic approach for predicting sediment transport from fields and small catchments. Earth Surface Processes and Landforms, Vol. 23, 527-544.

Nearing, M. A., Foster, G. R., Lane, L. J., and Fincker, S. C. (1989) A process-based soil erosion model for USDA-Water Erosion Prediction Project technology. Transactions ASAE, Vol. 32, 1587-1593.

Nel, W. (2007) Intra-storm attributes of extreme storm events in the Drakensberg, South Africa. Physical Geography, Vol. 28, 158-169. 
Nel, W. and Sumner, P. D. (2007) Intensity, energy, and erosivity attributes of rainstorms in the KwaZulu-Natal Drakensberg, South Africa. South African Journal of Science, Vol. 103, 398-402.

Nigel, R. and Rughooputh, S. D. D. V. (2010a) Mapping of monthly soil erosion risk of Mauritius and its aggregation with delineated basins. Geomorphology, Vol. $114,101-114$.

Nigel, R. and Rughooputh, S. D. D. V. (2010b) Mapping soil erosion risk with new datasets: An improved identification and prioritisation of high erosion areas. Catena, Vol. 82, 191-205.

Nyssen, J., Vandenreyken, H., Poesen, J., Moeyersons, J., Deckers, J., Haile, M., Salles, C., and Goyers, G. (2005) Rainfall erosivity and variability in the Northern Ethiopian Highlands. Journal of Hydrology, Vol. 311, 172-187.

Obi, M. E. and Salako, F. K. (1995) Rainfall parameters influencing erosivity in southeastern Nigeria. Catena, Vol. 24, 275-287.

Padya, B. M. (1989) Weather and Climate of Mauritius. Moka, Mauritius: The Mahatma Ghandi Institute Press.

Rughooputh, S. D. D. V. (1997) Climate Change and Agriculture: Microclimatic Considerations. Reduit, Mauritius: AMAS, Food and Agricultural Research Council,

Rydgren, B. (1996) Soil erosion: Its measurement, effects, and prediction. Case study from the southern Lesotho lowlands. Zeitschrift für Geomorphologie, Vol. 40, $429-445$.

Schulze, R. E. (1978) Rainfall intensities, kinetic energies, and probabilities: Examples of applied climatological studies of Natal. Water SA, Vol. 4, 179-191.

Stocking, M. A. and Elwell, H. A. (1976) Rainfall erosivity over Rhodesia. Transactions of the Institute of British Geographers NS, Vol. 1, 231-245.

Suarez de Castro, F. (1950) Relaciones entre las lluvias y la erosion [Relations between rainfall and erosion]. Agricultura Tropical (Bogota), Vol. 6, 45-47.

Trustrum, N. A., Gomez, B., Reid, L. M., Page, M. J., and Hicks, D. M. (1999) Sediment production, storage, and output: The relative role of large-magnitude events in steepland catchments. Zeitschrift für Geomorphologie, Vol. 115, 71-86.

Van Dijk, A., Bruijnzeel, L., and Rosewell, C. (2002) Rainfall intensity-kinetic energy relationships: A critical literature appraisal. Journal of Hydrology, Vol. 261, 1-23.

Wischmeier, W. H. and Smith, D. D. (1978) Rainfall energy and its relation to soil loss. Transactions of the American Geophysical Union, Vol. 39, 285-291.

WRU (Water Resources Unit) (2007) Hydrology Data Book for Period 2000-2005. Rose-Hill, Mauritius. Water Resources Unit.

WRU and GIBB (2002) Watershed Management, 4. Report for the Land Drainage Study of Mauritius Island. Solferino, Mauritius: GIBB (Mauritius) Ltd. for Water Resources Unit, Mauritius.

Yahya, B. M., Devi, N. M., and Umrikar, B. (2010) Flood hazard mapping by integrated GIS-SCS model. International Journal of Geomatics and Geosciences, Vol. 1, 489-500.

Yen, M. and Chen, T. (2000) Seasonal variation of the rainfall over Taiwan. International Journal of Climatology, Vol. 20, 803-809. 